\title{
Thermodynamic Feasibility of Hydrogen-Rich Gas Production Supported by Iron Based Chemical Looping Process
}

\author{
Grzegorz Słowiński ${ }^{1}$ and Adam Smoliński \\ ${ }^{1}$ Department of Engineering, Vistula University, 3 Stokłosy Street, 02-787 Warsaw, Poland \\ ${ }^{2}$ Central Mining Institute, Department of Energy Saving and Air Protection, Plac Gwarkow 1, 40-166 Katowice, Poland \\ Correspondence should be addressed to Adam Smoliński; smolin@gig.katowice.pl
}

Received 3 June 2016; Revised 25 July 2016; Accepted 27 July 2016

Academic Editor: Thijs A. Peters

Copyright ( 2016 G. Słowiński and A. Smoliński. This is an open access article distributed under the Creative Commons Attribution License, which permits unrestricted use, distribution, and reproduction in any medium, provided the original work is properly cited.

\begin{abstract}
The continuously increasing oil prices as well as stronger environmental regulations regarding greenhouse emissions made the greatest economic powers search a new, price competitive, and environment friendly energy carrier, such as hydrogen. The world research activities in these terms focus on the development of integrated hydrogen and power generating technologies, particularly technologies of hydrogen production from various carbonaceous resources, like methane, coal, biomass, or waste, often combined with carbon dioxide capture. In the paper the thermodynamic analysis of the enhancement of hydrogen production in iron based chemical looping process is presented. In this method, iron oxide is first reduced to iron with a reducing agent, such as carbon oxide, hydrogen, or mixture of both gases (synthesis gas), and then, in the inverse reaction with steam, it is regenerated to iron oxide, and pure stream of hydrogen is produced.
\end{abstract}

\section{Introduction}

Nowadays fossil fuel combustion process, particularly combustion of coal, contributes significantly to the increasing, negative environmental impact of a power sector [1-7]. The limited resources of fossil fuels, unstable oil and gas market, and restrictive environmental regulations regarding greenhouse gases emission imply the need for the development of price competitive and environment friendly energy carriers, like hydrogen [8-13]. It is environmentally neutral and may be produced in the process of steam gasification of coal or biomass/waste, reducing the carbon footprint of the power sector and contributing to the development of innovative clean coal technologies.

Hydrogen-rich gas production in gasification process is combined with $\mathrm{CO}_{2}$ separation, in two main steps [13-19].

(I) The gasification step, in which coal is gasified to syngas and iron oxide is applied to oxidize carbon monoxide present in syngas and to enhance the Boudouard reaction (3) generating carbon dioxide and amorphous carbon:

$$
\mathrm{C}+\mathrm{H}_{2} \mathrm{O}_{(\mathrm{g})}=\mathrm{CO}_{(\mathrm{g})}+\mathrm{H}_{2(\mathrm{~g})}
$$

$$
\begin{aligned}
\mathrm{CO}_{(\mathrm{g})}+\mathrm{H}_{2} \mathrm{O}_{(\mathrm{g})} & =\mathrm{CO}_{2(\mathrm{~g})}+\mathrm{H}_{2(\mathrm{~g})} \\
2 \mathrm{CO}_{(\mathrm{g})} & =\mathrm{CO}_{2(\mathrm{~g})}+\mathrm{C} \\
\mathrm{CH}_{4(\mathrm{~g})}+\mathrm{H}_{2} \mathrm{O}_{(\mathrm{g})} & =\mathrm{CO}_{(\mathrm{g})}+3 \mathrm{H}_{2(\mathrm{~g})} \\
\mathrm{CH}_{4(\mathrm{~g})}+\mathrm{CO}_{2(\mathrm{~g})} & =2 \mathrm{CO}_{(\mathrm{g})}+2 \mathrm{H}_{2(\mathrm{~g})} \\
\mathrm{C}+2 \mathrm{H}_{2(\mathrm{~g})} & =\mathrm{CH}_{4(\mathrm{~g})} \\
1.126 \mathrm{Fe}_{2} \mathrm{O}_{3}+\mathrm{CO}_{(\mathrm{g})} & =2.378 \mathrm{Fe}_{0.947} \mathrm{O}+\mathrm{CO}_{2(\mathrm{~g})} \\
1.126 \mathrm{Fe}_{2} \mathrm{O}_{3}+\mathrm{C} & =\mathrm{CO}_{(\mathrm{g})}+2.378 \mathrm{Fe}_{0.947} \mathrm{O} \\
1.126 \mathrm{Fe}_{2} \mathrm{O}_{3}+\mathrm{H}_{2(\mathrm{~g})} & =2.378 \mathrm{Fe}_{0.947} \mathrm{O}+\mathrm{H}_{2} \mathrm{O}_{(\mathrm{g})}
\end{aligned}
$$

(II) Capture of carbon dioxide with $\mathrm{CaO}$ :

$$
\mathrm{CaO}+\mathrm{CO}_{2(\mathrm{~g})}=\mathrm{CaCO}_{3}
$$

Iron and iron oxide $\left(\mathrm{Fe}_{0.947} \mathrm{O}\right)$ is oxidized in oxygen or in air, and the heat from this exothermic reaction is utilized in calcination of calcium carbonate, generating a sequestration 


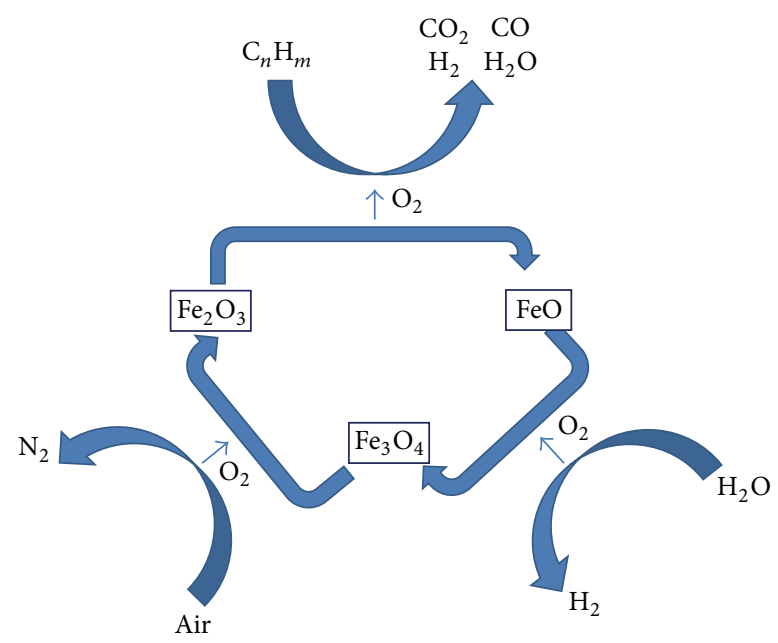

FIGURE 1: The concept of hydrogen-rich gas production supported by chemical looping process.

ready stream of $\mathrm{CO}_{2}$. In the paper the idea and thermodynamic analysis of the enhanced hydrogen production in iron based chemical looping process are presented. Iron oxide is first reduced to iron with a reducing agent, such as carbon oxide, hydrogen, or mixture of both gases (synthesis gas from gasification process), and then, in the inverse reaction with steam, it is regenerated to iron oxide, and pure stream of hydrogen is produced. The idea of the process is presented in Figure 1.

\section{Thermodynamic Approach of the Process}

The idea of hydrogen production from syngas with the application of iron oxide as an oxygen transfer compound requires systematic thermodynamic calculations [20-22] to assess the feasibility of the process. In the paper the calculations of free Gibbs energies $(G)$ at various temperatures were presented (see Supplementary Material available online at http://dx.doi.org/10.1155/2016/1764670). The free Gibbs energies of the studied reactions were calculated with the application of the HSC Chemistry ver. 3.0 [23].

The change in the free Gibbs energy of the system during the reaction is the results of the subtraction of change of the temperature and the entropy of the system multiplication result from the system enthalpy change. Mathematically it can be presented as follows:

$$
\Delta G=\Delta H-\Delta(T S),
$$

where $T$ denotes the temperature in $\mathrm{K}$.

On the basis of the value of the heat given off or absorbed, the reactions can be classified as either exothermic $(\Delta H<0)$ or endothermic $(\Delta H>0)$. The same classification could be made based on the free Gibbs energy of the system, which may decrease (exergonic reaction: $\Delta G<0$ ) or increase during the reaction (endergonic reaction: $\Delta G>0$ ).

There exist three thermodynamically stable iron oxides, such as nonstoichiometric ferrous oxide, also called wustite, ferric oxide, known as hematite (iron (III) oxide: $\mathrm{Fe}_{2} \mathrm{O}_{3}$ ),

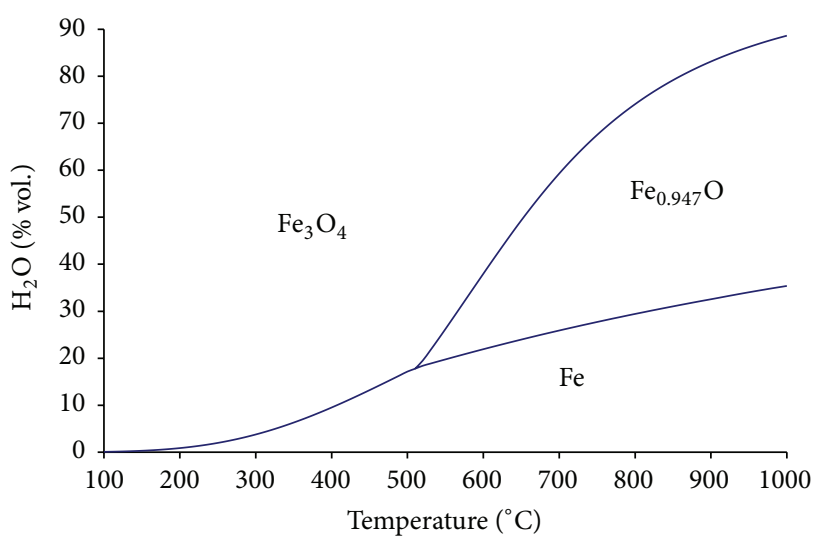

FIgURE 2: The phase stability diagram of $\mathrm{Fe}, \mathrm{Fe}_{0.947} \mathrm{O}$, and $\mathrm{Fe}_{3} \mathrm{O}_{4}$ phases in $\mathrm{H}_{2} \mathrm{O}-\mathrm{H}_{2}$ atmosphere.

and ferrous ferric oxide (iron (II, III) oxide: $\mathrm{Fe}_{3} \mathrm{O}_{4}$ ), named magnetite or lodestone. Nonstoichiometric wustite is usually denoted by $\mathrm{Fe}_{0.947} \mathrm{O}$. There are a number of nonstoichiometric iron oxides of the general formula $\mathrm{Fe}_{(1-x)} \mathrm{O}$, where $x$ denotes a number between 0 and 0.1 . It means that the equilibrium diagram of $\mathrm{Fe} / \mathrm{FeO} / \mathrm{Fe}_{3} \mathrm{O}_{4}$ in $\mathrm{H}_{2}-\mathrm{H}_{2} \mathrm{O}$ atmosphere at higher temperatures will be more complex. The thermochemical tables, however, usually include only $\mathrm{Fe}_{0.947} \mathrm{O}$ phase. Moreover, in the literature the formula of wustite is often presented as FeO (iron (II) oxide).

\section{Results and Discussion}

3.1. Iron Oxidation with Steam. Iron can be oxidized with steam to magnetite $\left(\mathrm{Fe}_{3} \mathrm{O}_{4}\right)$ or nonstoichiometric wustite $\left(\mathrm{Fe}_{0.947} \mathrm{O}\right)$. Iron oxidation with steam to hematite $\left(\mathrm{Fe}_{2} \mathrm{O}_{3}\right)$ is thermodynamically unfeasible, which may be easily confirmed by considering the equilibrium atmosphere composition for the reaction of magnetite oxidation to hematite. The possible chemical reactions in a system of $\mathrm{Fe}, \mathrm{Fe}_{3} \mathrm{O}_{4}$, and $\mathrm{Fe}_{0.947} \mathrm{O}$ in $\mathrm{H}_{2} / \mathrm{H}_{2} \mathrm{O}$ atmosphere are as follows:

$$
\begin{aligned}
0.75 \mathrm{Fe}+\mathrm{H}_{2} \mathrm{O} & =0.25 \mathrm{Fe}_{3} \mathrm{O}_{4}+\mathrm{H}_{2} \\
0.947 \mathrm{Fe}+\mathrm{H}_{2} \mathrm{O} & =\mathrm{Fe}_{0.947} \mathrm{O}+\mathrm{H}_{2} \\
3.807 \mathrm{Fe}_{0.947} \mathrm{O}+\mathrm{H}_{2} \mathrm{O} & =1.202 \mathrm{Fe}_{3} \mathrm{O}_{4}+\mathrm{H}_{2}
\end{aligned}
$$

Figure 2 presents the phase stability diagram for this system. The triple point of the diagram is situated at $510^{\circ} \mathrm{C}$ and at $17.8 \%$ vol. steam. This temperature is lower than the values usually cited of $571^{\circ} \mathrm{C}[24]$ or $567^{\circ} \mathrm{C}[25]$.

The diagram can be applied in evaluation of the theoretical limitations of gas composition produced by iron oxidation or iron oxides reduction. In the hydrogen production process, iron is introduced into the $\mathrm{H}_{2} \mathrm{O}$-rich atmosphere, where it is unstable (see Figure 2). During Fe-steam reaction (12), steam is consumed and hydrogen is produced. As a result, the atmosphere composition changes in the direction of more hydrogen-rich states. When the atmosphere composition achieves the borderline between iron and iron oxide stability regions, $\Delta G$ for oxidation reaction reaches zero, the Fe 
becomes stable, and the reaction stops. Thus, the possible compositions of gaseous mixture produced during Fe-steam reaction are situated above the borderline dividing Fe-iron oxides region. Similarly, the reduction of iron oxides to Fe is possible by introducing iron oxides to the region of $\mathrm{Fe}$ stability, and the composition of the reduction reaction gas product can be found below the borderline dividing Fe and iron oxides regions.

At the temperatures below the triple point, it is possible to produce $1.33 \mathrm{~mol}$ of hydrogen per $1 \mathrm{~mol}$ of iron (see reaction (12)). The maximum thermodynamically feasible concentration of hydrogen varies from $99.9 \%$ vol. at $100^{\circ} \mathrm{C}$ to $82.8 \%$ vol. at $500^{\circ} \mathrm{C}$. Above the triple point, it is possible to produce $1.06 \mathrm{~mol}$ of hydrogen from $1 \mathrm{~mol}$ of $\mathrm{Fe}$ in reaction (13) or $1.33 \mathrm{~mol}$ of $\mathrm{H}_{2}$ in reaction (12). In case of reaction (13), the maximum thermodynamically viable hydrogen concentration varies from $78 \%$ vol. at $600^{\circ} \mathrm{C}$ to $64.6 \%$ vol. at $1000^{\circ} \mathrm{C}$. Performing reaction (12) under the conditions above the triple point would result in the achievable hydrogen concentrations between $62.0 \%$ vol. at $600^{\circ} \mathrm{C}$ and $11.4 \%$ vol. at $1000^{\circ} \mathrm{C}$. In general, the steam-iron reaction requires possibly low temperature to ensure the potentially highest hydrogen concentration and, at the same time, reasonable process kinetics. The reaction kinetics could be improved by $\mathrm{Fe}$ doping with other metals, exhibiting catalytic effects [20, 21]. Applying the lower temperature is also beneficial for Fe structure stability degrading at higher temperatures. However, the elevated temperatures cannot be avoided in the reduction stage. The presence of a few percentages of steam in hydrogen gas should not pose any serious operational problems. In fact, low temperature Polymer Electrolyte Membrane Fuel Cells (PEMFCs), applicable as potential hydrogen consumers, require membrane wetting $[12,26]$. If necessary, water can be removed from hydrogen by cooling and condensation.

3.2. Iron Oxides Reduction with Hydrogen. Iron oxides reduction with hydrogen is reverse to the oxidation, and the thermochemical limitations of the process are given in Figure 2. It can be seen that $\mathrm{Fe}_{3} \mathrm{O}_{4}$ or $\mathrm{Fe}_{0.947} \mathrm{O}$ reduction to metallic iron terminates at relatively low concentration of steam in $\mathrm{H}_{2}-\mathrm{H}_{2} \mathrm{O}$ atmosphere. At $100^{\circ} \mathrm{C}$ it is $0.1 \%$ vol. steam, and it grows to $35.4 \%$ vol. at $1000^{\circ} \mathrm{C}$. Thus, the higher temperatures are favorable for the reduction stage. However, even at higher temperature (of $1000^{\circ} \mathrm{C}$ ), if iron oxides are to be reduced in a flow of hot hydrogen, the flue gas will still contain over $60 \%$ vol. of hydrogen. This implies that hydrogen needs to be separated from hydrogen/steam stream and recycled.

3.3. Iron Oxides Reduction with Carbon Monoxide. The iron oxides reduction process may be performed with carbon oxide, according to the following reactions:

$$
\begin{aligned}
0.25 \mathrm{Fe}_{3} \mathrm{O}_{4}+\mathrm{CO} & =0.75 \mathrm{Fe}+\mathrm{CO}_{2} \\
\mathrm{Fe}_{0.947} \mathrm{O}+\mathrm{CO} & =0.947 \mathrm{Fe}+\mathrm{CO}_{2} \\
1.202 \mathrm{Fe}_{3} \mathrm{O}_{4}+\mathrm{CO} & =3.807 \mathrm{Fe}_{0.947} \mathrm{O}+\mathrm{CO}_{2}
\end{aligned}
$$

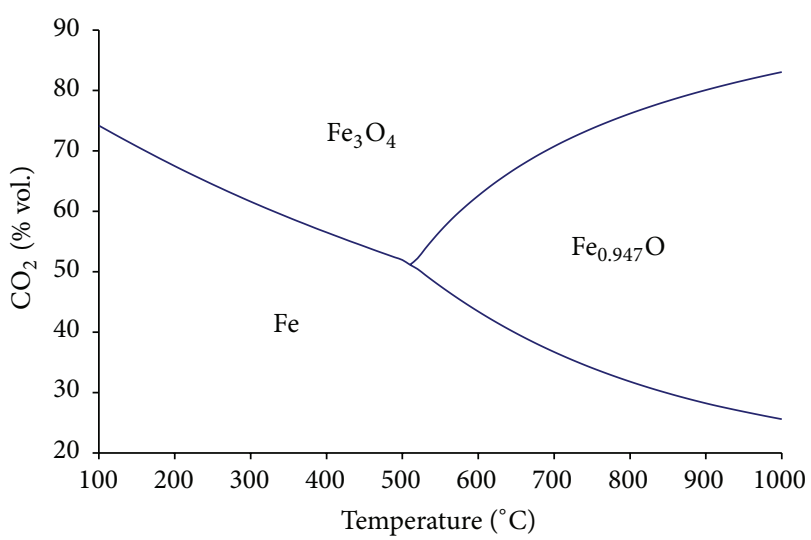

Figure 3: The phase stability diagram of $\mathrm{Fe}, \mathrm{Fe}_{0.947} \mathrm{O}$, and $\mathrm{Fe}_{3} \mathrm{O}_{4}$ phases in $\mathrm{CO}-\mathrm{CO}_{2}$ atmosphere.

Figure 3 presents the phase stability diagram for the system $\mathrm{Fe} / \mathrm{Fe}_{0.947} \mathrm{O} / \mathrm{Fe}_{3} \mathrm{O}_{4}$ in the $\mathrm{CO}-\mathrm{CO}_{2}$ atmosphere. The maximum utilization of $\mathrm{CO}$ in $\mathrm{Fe}_{3} \mathrm{O}_{4}$ reduction decreases from $74 \%$ vol. at $100^{\circ} \mathrm{C}$ to $26 \%$ vol. at $1000^{\circ} \mathrm{C}$. This means that the reduction should be done at possibly low temperature for the optimal utilization of CO. Three other aspects, however, need to be also considered. First, the reaction kinetics may be insufficient at low temperatures; second, low temperatures are thermodynamically favorable for carbon deposition in the Boudouard reaction [18, 27]; and, third, the reduction may be performed with the application of synthesis gas, rather than with a pure CO stream. As it was shown in Section 3.2, the reduction of magnetite with hydrogen is more efficient at high temperatures.

3.4. Iron Oxides Reduction with Methane. It is assumed that iron oxide reduction with methane goes through the reactions:

$$
\begin{aligned}
\mathrm{Fe}_{3} \mathrm{O}_{4}+\mathrm{CH}_{4} & =3 \mathrm{Fe}+\mathrm{CO}_{2}+2 \mathrm{H}_{2} \mathrm{O} \\
4 \mathrm{Fe}_{0.947} \mathrm{O}+\mathrm{CH}_{4} & =3.788 \mathrm{Fe}+\mathrm{CO}_{2}+2 \mathrm{H}_{2} \mathrm{O} \\
4.807 \mathrm{Fe}_{3} \mathrm{O}_{4}+\mathrm{CH}_{4} & =15.228 \mathrm{Fe}_{0.947} \mathrm{O}+\mathrm{CO}_{2}+2 \mathrm{H}_{2} \mathrm{O}
\end{aligned}
$$

$\mathrm{H}_{2}$, CO, and $\mathrm{C}$ do not constitute the products of the reduction reactions. In Figure 4 the phase stability diagram for the system $\mathrm{Fe} / \mathrm{Fe}_{0.947} \mathrm{O} / \mathrm{Fe}_{3} \mathrm{O}_{4}$ in the $\mathrm{CH}_{4}-\mathrm{CO}_{2}-\mathrm{H}_{2} \mathrm{O}$ atmosphere is presented. It can be seen that the reaction equilibrium depends strongly on the temperature; high consumption of methane is achieved at relatively high temperatures. Increased pressure moves the equilibrium borders to higher temperatures range.

3.5. Remarks on a Reducing Gas Consumption in the Iron Oxides Reduction Process. The reduction of magnetite at temperatures over the triple point proceeds in the order of magnetite, wustite, and then iron. It could be explained on the example of magnetite reduction with hydrogen at $800^{\circ} \mathrm{C}$. 


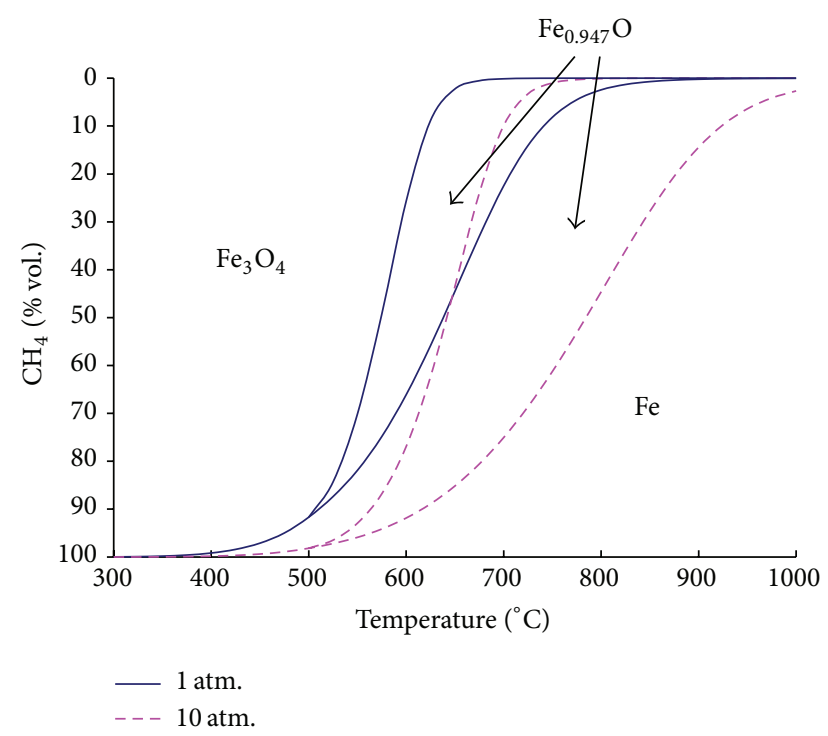

FIgURE 4: The phase stability diagram of $\mathrm{Fe}, \mathrm{Fe}_{0.947} \mathrm{O}$, and $\mathrm{Fe}_{3} \mathrm{O}_{4}$ phases in the $\mathrm{CH}_{4}-\mathrm{CO}_{2}-\mathrm{H}_{2} \mathrm{O}$ atmosphere.

$10 \mathrm{~mol}$ of $\mathrm{Fe}_{3} \mathrm{O}_{4}$ can be reduced at $800^{\circ} \mathrm{C}$ in a single stage by blowing with pure hydrogen. The necessary amount of $\mathrm{H}_{2}$ is given by the following equation:

$$
\mathrm{N}_{\mathrm{H}_{2}}=\frac{4 \cdot 10 \mathrm{~mol}}{29.43 \%}=135.92 \mathrm{~mol}
$$

The process consumes $135.92 \mathrm{~mol}$ of pure $\mathrm{H}_{2}$. The flue gas produced contains $40 \mathrm{~mol}$ of $\mathrm{H}_{2} \mathrm{O}(29.43 \%$ vol.) and $95.92 \mathrm{~mol}$ of $\mathrm{H}_{2}$ (70.57\% vol.). The same process could be conducted in two stages. In the first one magnetite is reduced to wustite in reversed reaction (14). The hydrogen consumption is

$$
\mathrm{N}_{\mathrm{H}_{2}}^{1}=\frac{10 \mathrm{~mol}}{1.202 \cdot 74.07 \%}=11.23 \mathrm{~mol}
$$

The reaction produces $(10 \cdot 3.807) / 1.202=31.67 \mathrm{~mol} \mathrm{Fe}_{0.947} \mathrm{O}$. The flue gas is composed of $8.32 \mathrm{~mol}$ of $\mathrm{H}_{2} \mathrm{O}(74.07 \% \mathrm{vol}$.) and $2.91 \mathrm{~mol}$ of $\mathrm{H}_{2}$ (25.93\% vol.).

In the second stage wustite is reduced to iron in reversed reaction (16). The hydrogen consumption is

$$
\mathrm{N}_{\mathrm{H}_{2}}^{2}=\frac{31.67 \mathrm{~mol}}{29.43 \%}=107.61 \mathrm{~mol}
$$

The flue gas contains $31.67 \mathrm{~mol}$ of $\mathrm{H}_{2} \mathrm{O}(29.43 \%$ vol.) and $75.94 \mathrm{~mol}$ of $\mathrm{H}_{2}$ (70.57\% vol.).

In total, in the second case of reduction (two-stage process) $118.83 \mathrm{~mol}$ of $\mathrm{H}_{2}$ is consumed, which is $17.69 \mathrm{~mol}$ less than in the single-stage process. The flue gas from the reduction of wustite to iron contains enough $\mathrm{H}_{2}$ to transform magnetite to wustite. This creates an additional opportunity for improved gas management in case that several iron containing reactors are applied. The flue gas from the $\mathrm{Fe}_{0.947} \mathrm{O} / \mathrm{Fe}$ stage in one reactor may be utilized for driving the $\mathrm{Fe}_{3} \mathrm{O}_{4} / \mathrm{Fe}_{0.947} \mathrm{O}$ reaction in the next reactor.

\section{Summary and Conclusions}

On the basis of the thermodynamic analysis of the enhanced hydrogen production in iron based chemical looping process it may be concluded that the steam-iron reaction should be carried out at possibly low temperature, ensuring the potentially highest hydrogen concentrations and, at the same time, reasonable process kinetics.

Analysis of the phase stability diagram of $\mathrm{Fe}, \mathrm{Fe}_{0.947} \mathrm{O}$, and $\mathrm{Fe}_{3} \mathrm{O}_{4}$ phases in $\mathrm{H}_{2} \mathrm{O}-\mathrm{H}_{2}$ atmosphere allowed concluding that, at temperatures below the triple point, it is feasible to produce $1.33 \mathrm{~mol}$ of hydrogen per $1 \mathrm{~mol}$ of iron. The maximum thermodynamically feasible concentration of hydrogen varies from $99.9 \%$ vol. at $100^{\circ} \mathrm{C}$ to $82.8 \%$ vol. at $500^{\circ} \mathrm{C}$.

Above the triple point of the phase stability diagram of $\mathrm{Fe}, \mathrm{Fe}_{0.947} \mathrm{O}$, and $\mathrm{Fe}_{3} \mathrm{O}_{4}$ phases in $\mathrm{H}_{2} \mathrm{O}-\mathrm{H}_{2}$ atmosphere, it is possible to produce $1.06 \mathrm{~mol}$ of hydrogen from $1 \mathrm{~mol}$ of $\mathrm{Fe}$ (in the reaction $0.947 \mathrm{Fe}+\mathrm{H}_{2} \mathrm{O}=\mathrm{Fe}_{0.947} \mathrm{O}+\mathrm{H}_{2}$ ) or $1.33 \mathrm{~mol}$ of hydrogen (in the reaction $0.75 \mathrm{Fe}+\mathrm{H}_{2} \mathrm{O}=0.25 \mathrm{Fe}_{3} \mathrm{O}_{4}+$ $\mathrm{H}_{2}$ ), respectively. The maximum thermodynamically feasible hydrogen concentration varies from $78.0 \%$ vol. at $600^{\circ} \mathrm{C}$ to $64.6 \%$ vol. at $1000^{\circ} \mathrm{C}$.

\section{Competing Interests}

The authors declare that they have no competing interests.

\section{Acknowledgments}

This work was supported by the Ministry of Science and Higher Education, Poland, under Grant no. 11310046.

\section{References}

[1] BP, BP Statistical Review of World Energy, BP, London, UK, 2015, http://www.bp.com/content/dam/bp/pdf/energy-economics/ statistical-review-2015/bp-statistical-review-of-world-energy2015-full-report.pdf.

[2] P. Chiesa, S. Consonni, T. Kreutz, and R. Williams, "Coproduction of hydrogen, electricity and $\mathrm{CO}_{2}$ from coal with commercially ready technology. Part A: performance and emissions," International Journal of Hydrogen Energy, vol. 30, no. 7, pp. 747-767, 2005.

[3] C.-C. Cormos, F. Starr, E. Tzimas, and S. Peteves, "Innovative concepts for hydrogen production processes based on coal gasification with $\mathrm{CO}_{2}$ capture," International Journal of Hydrogen Energy, vol. 33, no. 4, pp. 1286-1294, 2008.

[4] C.-C. Cormos, "Evaluation of energy integration aspects for IGCC-based hydrogen and electricity co-production with carbon capture and storage," International Journal of Hydrogen Energy, vol. 35, no. 14, pp. 7485-7497, 2010.

[5] DOE NETL Department of Energy and National Energy Technology Laboratory, Gasification Technology Database, 2010, http://www.netl.doe.gov.

[6] P. Rompalski, A. Smoliński, H. Krztoń, J. Gazdowicz, N. Howaniec, and L. Róg, "Determination of mercury content in hard coal and fly ash using X-ray diffraction and scanning electron microscopy coupled with chemical analysis," Arabian Journal of Chemistry, 2016. 
[7] A. Smoliński, M. Stempin, and N. Howaniec, "Determination of rare earth elements in combustion ashes from selected Polish coal mines by wavelength dispersive X-ray fluorescence spectrometry," Spectrochimica Acta Part B: Atomic Spectroscopy, vol. 116, pp. 63-74, 2016.

[8] EIA, Annual Energy Outlook 2015 with Projections to 2040, U.S. Energy Information Administration (EIA), Washington, DC, USA, 2015, http://www.eia.gov/forecasts/aeo/.

[9] A. Hafizi, M. R. Rahimpour, and S. Hassanajili, "Calcium promoted $\mathrm{Fe} / \mathrm{Al}_{2} \mathrm{O}_{3}$ oxygen carrier for hydrogen production via cyclic chemical looping steam methane reforming process," International Journal of Hydrogen Energy, vol. 40, no. 46, pp. 16159-16168, 2015.

[10] N. Howaniec, A. Smoliński, and M. Cempa-Balewicz, "Experimental study on application of high temperature reactor excess heat in the process of coal and biomass co-gasification to hydrogen-rich gas," Energy, vol. 84, pp. 455-461, 2015.

[11] N. Howaniec, A. Smoliński, K. Stańczyk, and M. Pichlak, "Steam co-gasification of coal and biomass derived chars with synergy effect as an innovative way of hydrogen-rich gas production," International Journal of Hydrogen Energy, vol. 36, no. 22, pp. 14455-14463, 2011.

[12] N. Katiyar, S. Kumar, and S. Kumar, "Polymer electrolyte membrane fuel cell grade hydrogen production by methanol steam reforming: a comparative multiple reactor modeling study," Journal of Power Sources, vol. 243, pp. 381-391, 2013.

[13] S. Lin, M. Harada, Y. Suzuki, and H. Hatano, " $\mathrm{CO}_{2}$ separation during hydrocarbon gasification," Energy, vol. 30, no. 11-12, pp. 2186-2193, 2005.

[14] S.-Y. Lin, Y. Suzuki, H. Hatano, and M. Harada, "Developing an innovative method, HyPr-RING, to produce hydrogen from hydrocarbons," Energy Conversion and Management, vol. 43, no. 9-12, pp. 1283-1290, 2002.

[15] S. Lin, M. Harada, Y. Suzuki, and H. Hatano, "Hydrogen production from coal by separating carbon dioxide during gasification," Fuel, vol. 81, no. 16, pp. 2079-2085, 2002.

[16] S. Lin, M. Harada, Y. Suzuki, and H. Hatano, "Process analysis for hydrogen production by reaction integrated novel gasification (HyPr-RING)," Energy Conversion and Management, vol. 46, no. 6, pp. 869-880, 2005.

[17] A. J. Minchener, "Coal gasification for advanced power generation," Fuel, vol. 84, no. 17, pp. 2222-2235, 2005.

[18] A. Smoliński, "Coal char reactivity as a fuel selection criterion for coal-based hydrogen-rich gas production in the process of steam gasification," Energy Conversion and Management, vol. 52, no. 1, pp. 37-45, 2011.

[19] F. Starr, E. Tzimas, and S. Peteves, "Critical factors in the design, operation and economics of coal gasification plants: the case of the flexible co-production of hydrogen and electricity," International Journal of Hydrogen Energy, vol. 32, no. 10-11, pp. 1477-1485, 2007.

[20] K. Otsuka, T. Kaburagi, C. Yamada, and S. Takenaka, "Chemical storage of hydrogen by modified iron oxides," Journal of Power Sources, vol. 122, no. 2, pp. 111-121, 2003.

[21] K. Otsuka and S. Takenaka, "Storage and supply of pure hydrogen mediated by the redox of iron oxides," Journal of the Japan Petroleum Institute, vol. 47, no. 6, pp. 377-386, 2004.

[22] J. Zhu, W. Wang, X. Hua, Z. Xia, and Z. Deng, "Simultaneous $\mathrm{CO}_{2}$ capture and $\mathrm{H}_{2}$ generation using $\mathrm{Fe}_{2} \mathrm{O}_{3} / \mathrm{Al}_{2} \mathrm{O}_{3}$ and $\mathrm{Fe}_{2} \mathrm{O}_{3}$ / $\mathrm{CuO} / \mathrm{Al}_{2} \mathrm{O}_{3}$ as oxygen carriers in single packed bed reactor via chemical looping process," Frontiers of Environmental Science and Engineering, vol. 9, no. 6, pp. 1117-1129, 2015.

[23] http://www.hsc-chemistry.net/.

[24] I. Barin, O. Knacke, and O. Kubaschewski, Thermodynamic Properties of Inorganic Substances, PA: Springer, Berlin, Germany, 1973.

[25] A. Pineau, N. Kanari, and I. Gaballah, "Kinetics of reduction of iron oxides by $\mathrm{H}_{2}$-part I: low temperature reduction of hematite," Thermochimica Acta, vol. 447, no. 1, pp. 89-100, 2006.

[26] A. Muthumeenal, S. S. Pethaiah, and A. Nagendran, "Investigation of SPES as PEM for hydrogen production through electrochemical reforming of aqueous methanol," Renewable Energy, vol. 91, pp. 75-82, 2016.

[27] K. Svoboda, G. Slowinski, J. Rogut, and D. Baxter, "Thermodynamic possibilities and constraints for pure hydrogen production by iron based chemical looping process at lower temperatures," Energy Conversion and Management, vol. 48, no. 12, pp. 3063-3073, 2007. 

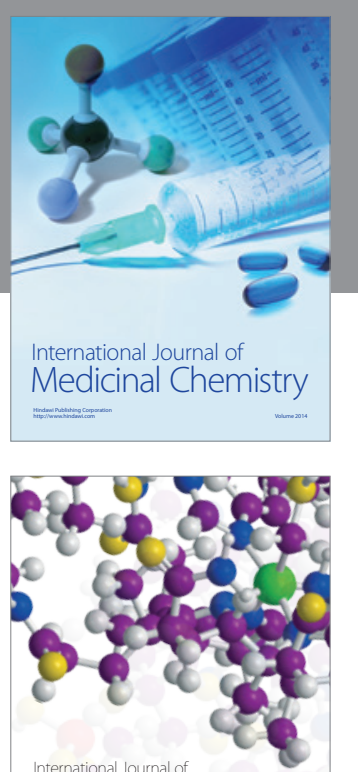

Carbohydrate Chemistry

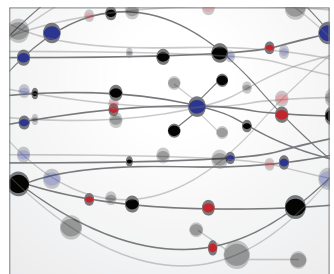

The Scientific World Journal
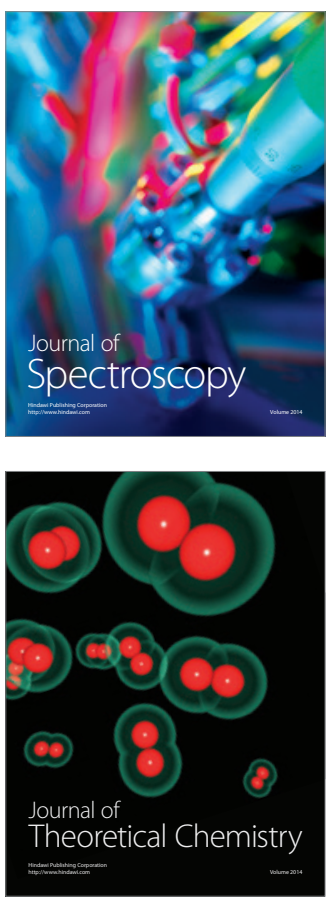
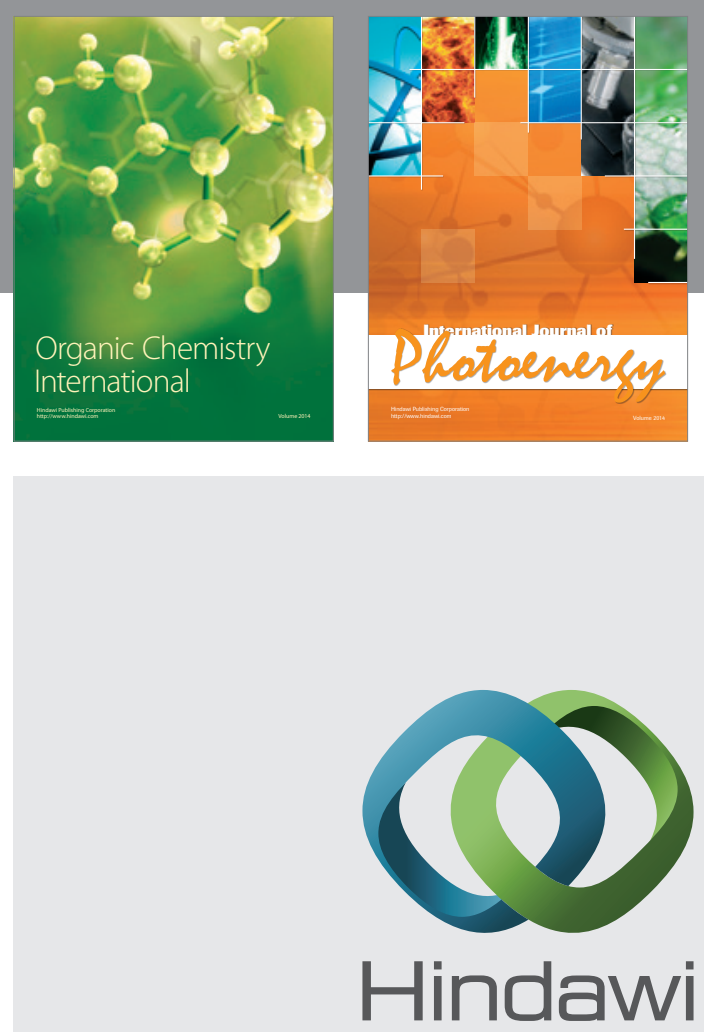

Submit your manuscripts at

http://www.hindawi.com

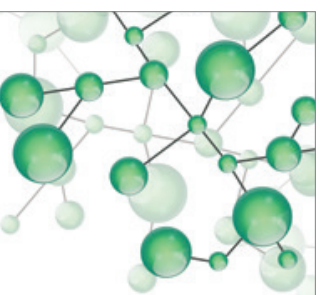

International Journal of

Inorganic Chemistry

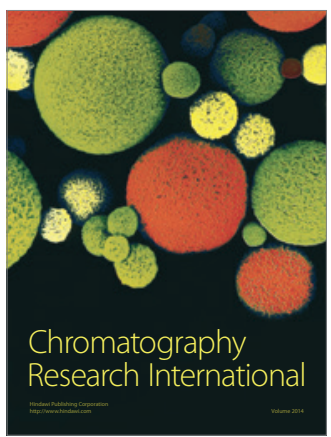

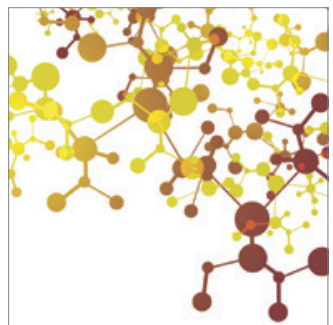

Applied Chemistry
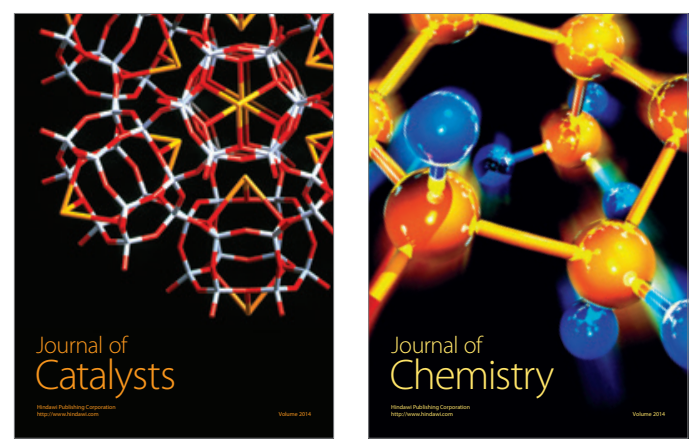
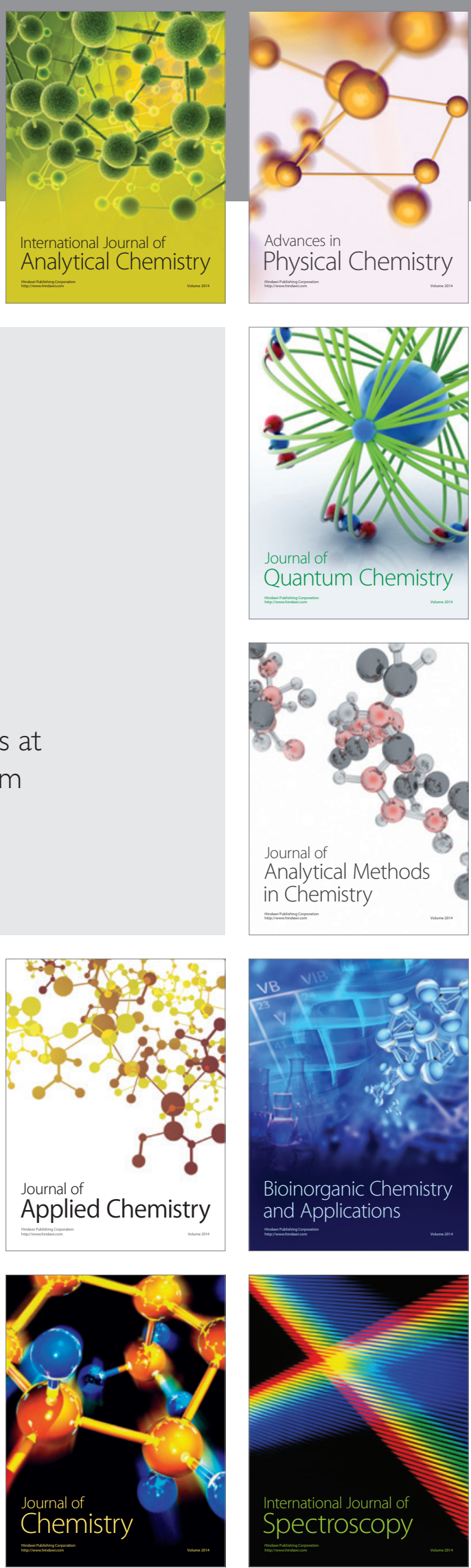